\title{
Gamechangers: A content and semiotic analysis of Super Bowl commercials during recession and non-recession years
}

Joshua Smithson

West Virginia University

Follow this and additional works at: https://researchrepository.wvu.edu/etd

\section{Recommended Citation}

Smithson, Joshua, "Gamechangers: A content and semiotic analysis of Super Bowl commercials during recession and non-recession years" (2013). Graduate Theses, Dissertations, and Problem Reports. 361. https://researchrepository.wvu.edu/etd/361

This Thesis is protected by copyright and/or related rights. It has been brought to you by the The Research Repository @ WVU with permission from the rights-holder(s). You are free to use this Thesis in any way that is permitted by the copyright and related rights legislation that applies to your use. For other uses you must obtain permission from the rights-holder(s) directly, unless additional rights are indicated by a Creative Commons license in the record and/ or on the work itself. This Thesis has been accepted for inclusion in WVU Graduate Theses, Dissertations, and Problem Reports collection by an authorized administrator of The Research Repository @ WVU. For more information, please contact researchrepository@mail.wvu.edu. 


\title{
Gamechangers: A content and semiotic analysis of Super Bowl commercials during recession and non-recession years
}

\author{
Joshua Smithson
}

Thesis submitted to the WVU Perley Isaac Reed School of Journalism in partial fulfillment of the requirements for the degree of

\section{MASTER OF SCIENCE IN JOURNALISM}

\author{
Steve Urbanski, Ph.D., Chair \\ James Ebel, M.B.A. \\ Tom Stewart, M.S.J. \\ Jensen Moore, Ph.D. \\ Morgantown, West Virginia \\ 2013
}

Keywords: Commercials; Advertising; Semiotic Analysis; Content Analysis; Super Bowl

Copyright 2013 Joshua Smithson 


\section{ABSTRACT \\ Gamechangers: A content and semiotic analysis of Super Bowl commercials during recession and non-recession years}

\section{Joshua Smithson}

The purpose of this study was to investigate the differences in symbolic content of Super Bowl commercials during recession and non-recession years. Another aim was to find out if humorous commercials were more common in recession year commercials as opposed to non-recession year commercials. Both quantitative and qualitative methods were applied. The study examined the topic through both content analysis and semiotic analysis. For the content analysis, commercials were viewed and coded to address the question of whether commercials change based on economic conditions. For the semiotic analysis, one commercial from each of the four selected years was chosen to be analyzed. The principle conclusion was that although the results are not significant, the findings are indeed significant. . It found that neither tone, product references, symbols, celebrity inclusion, or product type were affected by the economic climate. This indicates that the ads agencies are not adjusting sales strategies based on the economy. 


\section{TABLE OF CONTENTS}

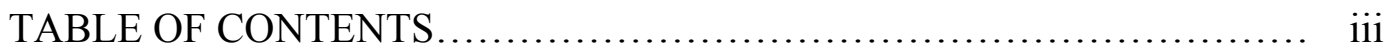

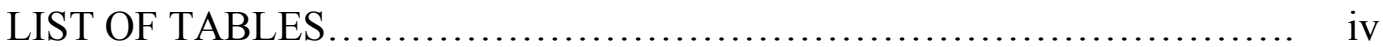

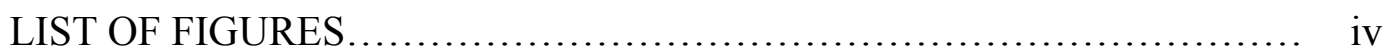

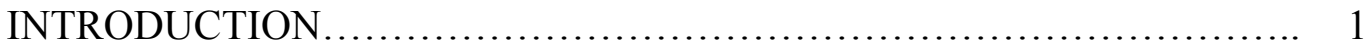

REVIEW OF LITERATURE \& RQ.................................. 4

METHODS........................................................ 15

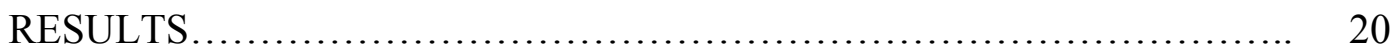

CONTENT ANALYSIS ......................................... 20

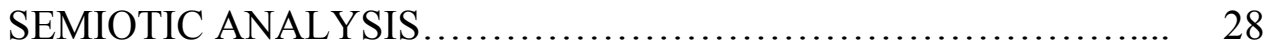

DISCUSSION AND CONCLUSION ................................. 39

LIMITS AND FUTURE STUDIES ................................... 42

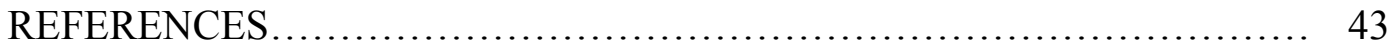

APPENDIX WITH CODEBOOK .................................. 46 


\section{LIST OF TABLES}

Table 1.1 . Frequency of broadcast $2009-2012$ by company name............... 21

Table 1.2. Overview of variability of symbols used from $2009-2012 \ldots \ldots \ldots \ldots \ldots . .23$

Table 1.3. Percentage of humorous commercials.......................... 23

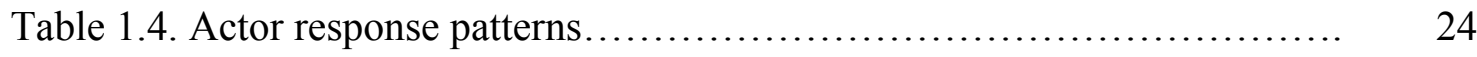

\section{LIST OF FIGURES}

Figure 1. Eastwood casts a large shadow................................ 30

Figure 2. Sculpting the physique..................................... 31

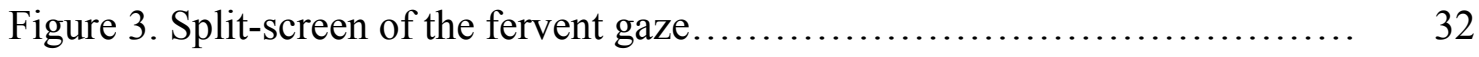

Figure 4. Statham carjacking a valet................................... 34

Figure 5. Comparison of Audi and Camaro jump shots...................... 37

Figure 6. Megan Fox bathing with her Xoom............................ 43 


\section{INTRODUCTION}

The broad issue and context for this study was commercials aired during the Super Bowl. This deals with the way the economy affects commercial making, which actually affects creation of meaning. Economic conditions have a strong influence on advertising images as representations, which are full of meanings. Commercials have a profound impact on today's people and culture. Television itself is one of the largest media influences on people's lives. Commercials stand in for something essential about our connection as social beings (Mitu, 2011). What differences, if any, are there between the symbols or strategies used during Super Bowl commercials during a recession year versus what they are like during a non-recession year? The primary concern of this research was to examine the effect of recessions on the symbolic content of Super Bowl commercials. A secondary concern was the extent to which advertising agencies may resort to humor to sell their products.

Why Super Bowl commercials?

There are a number of reasons why Super Bowl commercials, as advertising vehicles, are worthy of methodical investigation. First, the Super Bowl is the most-watched television event of the year (Kim \& Cheong, 2012). Recently Super Bowl telecasts have reached over $40 \%$ of the U.S. population, which amounts to over 90 million viewers (Kim \& Cheong, 2012). Advertising studies conducted by Leo Burnett's Starcom Media Services 
and Media That Works both concluded that the NFL championship is the leading advertising vehicle with adults - particularly those under 35 . The studies concluded that approximately $50 \%$ of viewers watched the game in the company of between two and five people; $26 \%$ of viewers consisted of six or more viewers, and approximately $22 \%$ of viewers watched the Super Bowl solo (Freeman, 1999).

Second, the Super Bowl reaches many demographics. The Super Bowl audience tends to be more balanced than other programming (McAllister, 1999). No demographic overlooks the Super Bowl. Such a wide variety of consumers make the Super Bowl an attractive venue for advertisers trying to broaden the appeal of their product.

The Super Bowl is played on the last Sunday in January or the first Sunday in February. In it, the champions from the National Football League play to determine the world champion (Super Bowl History 2006; NFL.com 2011). The Super Bowl is so popular that Super Bowl XLIV in 2010 was the most-watched program in history with a Nielsen rating of 36.5 (Nielsen Wire 2010). With the popularization of You Tube and AdBlitz viewers can re-watch commercials as often as they want. This massive circulation makes it even more important to study and analyze the usage of symbols and visual rhetoric in Super Bowl commercials. A great deal of money is spent on Super Bowl advertisementsthe cost of a typical 30-second ad during this year's telecast was $\$ 3.5$ million, up $\$ 500,000$ from the previous year (Vranica, 2012). Ad prices have shot up 59\% since 2001 (Vranica, 2012).

\section{Contribution to the Field}


There have been previous studies done on various aspects of Super Bowl commercials. For instance, in Picture perfect? A comparative-historical content analysis of women in Super Bowl commercials, Robin Gary used content analysis to study the use of women in Super Bowl ads over a 25-year period. Gary found that dominant images of women have not changed substantially over the period, and found evidence supporting her convergence and replacement hypotheses. Convergence was coded as commercials where a racially ambiguous woman is part of a multiracial group of men and women with no black woman present, part of a group of white women and no black women are present, or if the racially ambiguous woman is the only one featured in the advertisement. Replacement was coded as a situation where a black man was present as part of a group where no black woman was present. This was based on an observation of a trend where black men were increasingly being romantically or socially paired with non-black women.

In When are Super Bowl Advertisings Super? Jin-Woo Kim studied the relationship between Super Bowl commercials and the stock of the companies that advertise in it. Event study results found that advertising from 2004 to 2008 is positively related to abnormal stock returns for advertisers, and this indicated that market value of advertisers was positively related to likeable characters, emotional appeals, and approach messaging. This study used an approach similar to Gary's wherein all of the selected aspects of the commercials were coded; however, the overall intention was different; rather than trying to analyze the way women were used as subjects of the male gaze, this study analyzed the 
way symbols and visual rhetoric are used as subjects of the recession/economy. One similarity between our studies is the category of the attractive woman in Super Bowl commercials. Because it is a male-dominated event (Nielsen Wire 2010) it is only logical that attractive women would be ubiquitous in the commercials.

In order to explore how advertisers alter their messages during economic downturns, this research will first review what a recession is and how it affects advertising in general. Next, it will give an overview of semiotics and the importance of this discipline in understanding and analyzing imagery/text. Finally, it will address research questions with this literature in mind.

There is a great deal of literature on the significance of advertising and the Super Bowl, including the previous two papers, but very little exists on the intertwining of Super Bowls and advertising. Based on literature review on the construction of advertising images in the West and research on humor, this study could open new vistas of academic study concerning the way advertisements react to changes in the economy.

\section{LITERATURE REVIEW}


Advertising During a Recession

Recessions are recurring events in all world economies. Although it may be triggered by what is happening in a single sector, its effects are widespread (Lilien, 2011). Recessions indicate a significant contraction in customer demand for goods and services, which lowers cash flow, sales, and profits. According to Julius Shiskin, a recession is defined as "a decline in the seasonally and calendar adjusted real gross domestic product (GDP) in at least two successive quarters" (Abberger, 2008). During recessions many firms cut franchise-building investments in things like innovation and marketing in order to conserve resources (Lilien, 2011). There are two definitions of recession: the operational one, and one that is a more general feeling of a time period. One of Merriam Webster dictionary's definitions of recession is "a period of reduced economic activity"(Merriam Webster's, 2013). This definition was used for 2011 because a Gallup poll (Morgan, 2011) demonstrated that more than half of Americans at the time believed the country was in a recession, if not a depression.

During a recession customers will react in different ways. Many customers reduce their spending (Kotler, 2009). Two likely behaviors a customer will resort to are switching to lower-priced products and cutting back on driving (Kotler, 2009). Lilien (2011) agreed with Kotler (2009) that when reacting to a recession, customers will reduce or postpone discretionary purchases. They may even avoid purchasing products altogether (Lilien, 2011). 
The effects on advertising firms are equally negative. In the case of a recession sales are harder to come by, with the inevitable implications to advertising budgets (Ostheimer, 1980). Whatever a company's marketing posture may be in normal times, it will change during more turbulent times, especially during a downward spiral or recession (Kotler, 2009). Tellis (2009) agreed with Lilien (2011) that firms adjust their behavior in response to recessions by cutting back on advertising, decreasing price promotions, and increasing non-price promotions. Graham (2011) stated that reducing spending during recessions is counterintuitive: firms believe their share of industry spending rises as other companies cut or reduce their ad budgets. If they spend more, they get a larger share of the market because other firms are fearful and not spending. He stated that this has not been empirically studied. However, according to Tellis (2009), the effect of advertising has been analyzed in seven empirical studies. He found that the strategy that was adopted for the advertising during a recession had many effects that persisted for many years after the recession. Three of the findings were that cutting back on advertising during a recession generates no profits, not cutting back can increase sales, and firms that increase advertising generate profits.

So what do firms do during market turbulence? According to Okazaki (2011), it becomes ever more critical for companies to tirelessly and aggressively create a compelling case for their particular brand. The most effective tone is to focus on value. Lilien (2011) disagreed with Graham's notion that spending during recessions is counterintuitive. He believed that higher ad spending equals more profit. He stated:

When a highly leveraged firm increases its advertising spending during recessions, it is clearly prioritizing its advertising program. That increase 
suggests that it has something special to communicate about its products to differentiate it from its competitors in the marketplace during difficult economic times, leading to a greater increase in sales and profits for its advertising spending in recessions (p. 52).

If done strategically, advertising during a recession can be profitable despite consumer thrift. As the chart entitled "Keeping Score" indicated, the price of advertising during the big game has been rising steadily for the entire past decade, even managing to jump during the economic nightmare year of 2009 (Weissmann, 2012).

\section{Keeping Score \\ Estimated Super Bowl ad rates}

$\$ 4$ million

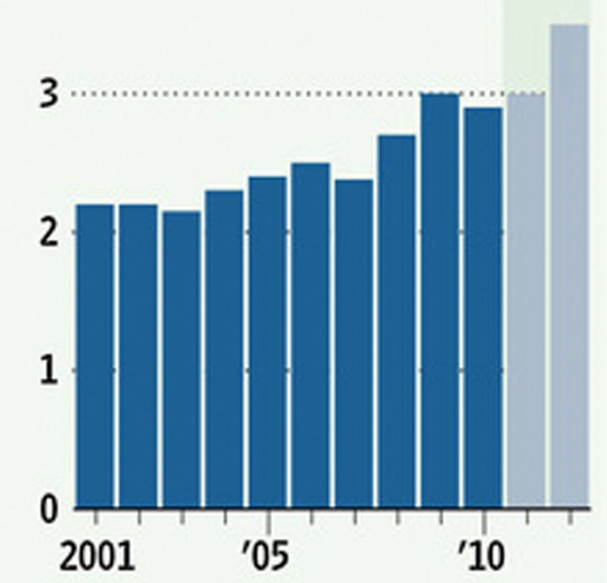

Note: 2011-12 figures are WSJ research estimates

Source: Kantar Media

Overall, the cost of a commercial is up 59\% since 2001. This indicates that even during a financial bust advertising spending can rise, which could be a critical factor in this paper, as it could help to explain internally contradicting data or data that contradicts the hypothesis. 
Signs, Dialogue, and Ideology

The relation between signs and ideology was theorized most directly by Mikhail Bakhtin (1929). Ideologies are systems of thoughts of an abstract nature that are applied to public matters. It is how individuals or society sees things. In Marxism and the Philosophy of Language, Bakhtin insisted that it is impossible to separate signs from ideology in terms of the "philosophy of language." Ideology has been termed anything from all utterances (Bakhtin, 1929) to any kind of idea (Destutt De Tracy, 1796) (Ponzio, 1993). Ideology cannot exist without signs, but signs can exist without ideology, as anything that is outside the human social realm such as genetic code or animal behavior is exempt. A relevant example for this study would be a commercial of a group of men driving trucks in a post-apocalyptic world. The ideology in that commercial would be the ideology of masculinity, and with Kress and Van Leeuwen (2001) in mind, it would be a discourse on many things, some of which would be male clothing fashion or automotive design and its relation to that masculinity. Ponzio (1993) stated that one does not necessarily become more familiar with ideology by defining it, but rather by examining the context of its use. Ponzio posited three conclusions concerning the question of the definition of ideology:

1: the statement 'ideology is false consciousness' is not a definition; 2: when we speak of ideology as false consciousness we are referring to bourgeois ideology which aims at the reproduction of class society and of social inequalities; 3 : by considering these aspects we soon become aware of the necessity of defining the word ideology in order to explain its different meanings, on the one hand, and suit the interpretation of ideology as social planning, on the other (p. 70). In agreement with 
Adam Schaff (1952), Ponzio eventually defined ideology as "either all those opinions which are formed under the influence of the interests of a specific class (genetic definition), or which are useful in defending the interests of a specific class (functional definition)"(p. 70). For Kress and Van Leeuwen (2001) ideology is a very useful and necessary mediating term: it is mediating in the sense that it accounts for the arrangements of discourses as well as in the sense of accounting for the relations between articulating and realization, as well as other social practices, organization and events. Umberto Eco (1986) identified ideology as "false consciousness." Ponzio disagrees with this view, stating that Eco dealt with stereotypes rather than ideology. Unlike ideology, stereotypes deal with uncontrollable, habitual, deep-rooted expectation (Ponzio, 1993).

Utilization of semiotics in advertising research

Using semiotics to study advertising can be traced back to the famous semiotician Roland Barthes. In Image/Music/Text Barthes (1977) performed a seminal analysis of a Panzani pasta advertisement. He used the advertisement to show that the image can be deconstructed into three different messages: the linguistic message, the coded iconic message, and the non-coded iconic message. The linguistic message is the caption and label of the product. These have the effect of affixing the preferred reading of the image. The coded iconic message concerns the imagery in the advertisement and what they evoke such as the open net bag and the idea of returning from the market. The non-coded message refers to the concrete objects in the advertisement; for instance, the onion signifies the presence of the actual object on the table. 
Huang (2010) addressed Barthes in his study Constructing the West in Chinese Magazine Advertising and used methodologies that are very pertinent to this study. Although it concerned magazine advertisements the study still has valuable avenues to apply to this study. The study discussed representations of minorities in mass media. His contention was that the West is mostly constructed through Western visual elements through advertisements for Chinese products. He found that to what extent Chinese advertisers used Western visual elements revealed the extent of Westernization (Huang, 2010). This was also a combination of semiotic analysis and content analysis. He stated that the two methods are complementary in that a combination of the two can give a larger picture of the questions under investigation, while at the same time they can generate results that can be arrived at only through the symbiosis of the two methods, by approaching the semiotic analysis quantitatively (Huang, 2010).

In his semiotic analysis he followed three major steps when analyzing individual advertisements. First, he recognized the surface meaning (the overall impression readers get from the ad). Next, he recognized the advertiser's intended meaning. Finally, he identified the cultural or ideological meaning. In the first step, Huang described what was in the advertising copy, including the four basic constituents of a print advertisement (the copy, headline, illustration, and logotype). In semiotic terms, the first step was to describe the signifier aspect of the sign. In the second step, Huang inferred what the possible messages the advertisement tried to get across, and how the message or proposition was made (for instance, "to use Chanel No. 5 is to be sexy"). In the third step, meaning 
derived from knowledge of the larger cultural background and other texts such as films, television shows and art were proposed (for instance, showing a female model in a seductive pose has been criticized for objectifying women, while female objectification is not the intention of the advertiser) (Huang, 2010). This study is not just useful for what it illuminates about semiotic analysis and content analysis, but also for its application to advertisements.

\section{Humor During A Recession}

The hypothesis of this study posits that during an economic downturn, advertising agencies may resort to humor to sell their products. It has been conjectured that humor is what some would call a psychological antidote to recessions. Anya Hindmarch in London's Financial Times points out "using fun to offset the pain of financial reality can provide not just a psychological outlet but tangible cost-effective solutions" (Friedman, 2009, p. 12). After using the humor strategy it was her best quarter ever, with revenue growth up $4 \%$ at a time when other luxury businesses were experiencing the opposite (Friedman, 2009). Research and market analysis for over 15 years have shown that a person's emotional reaction to an advertisement can be a motivator of spending habits and can significantly influence the state of mind of the consumer and their recall (Niazi, Ghani \& Aziz, 2012). The NHS (Nurses’ Health Study), and ongoing project, shells out taxpayers' money to hire a consultancy called Humour Us to discover fun in work during a recession. According to Penny de Valk, chief executive of the Institute of Leadership and Management, the power of humor to relieve stress is now widely recognized and supported by research (Braid, 2009). 
Theory

Semiotics is the science of signs. Swiss linguist Ferdinand de Saussure (1965) is considered the founder of semiology, while the American philosopher Charles Peirce is considered the founder of semiotics. Each science is involved with the system of sign interpretation. According to Saussure, signs are made of sounds and images, termed signifiers, and the concepts that these images and sounds bring to mind, termed signifieds. As Saussure wrote:

I call the combination of a concept and a sound-image a sign, but in current usage the term generally designates only a sound-image, a word, for example... I propose to retain the word sign [signe] to designate the whole and to replace concept and sound-image respectively by signified [signifie] and signifier [significant]; the last two terms have the advantage of indicating the opposition that separates them from each other and from the whole of which they are parts. As regards sign, if I am satisfied with it, this is simply because I do not know of any word to replace it, the ordinary language suggesting no other (p. 67)

The relationship is illustrated in the following chart:

\begin{tabular}{|c|c|}
\hline \multicolumn{2}{|c|}{$\begin{array}{llll} & \mathbf{I} & \mathbf{G} & \mathbf{N}\end{array}$} \\
\hline Signifier & Signified \\
\hline Sound-Image & Concept \\
\hline
\end{tabular}

Example:

George Washington Father of The United States

Peirce posited there were three types of signs: symbols, icons and indexes. Symbols signify things on the basis of convention, icons by resemblance, and indexes by cause and effect. Peirce (1990) wrote: 
Every sign is determined by its objects, either first by partaking in the characters of the object, when I call a sign an Icon; secondly, by being really and in its individual existence connected with the individual object, when I call the sign an Index; thirdly, by more or less approximate certainty that it will be interpreted as denoting the object, in consequence of a habit (which term I use as including a natural disposition), when I call the sign a Symbol (Berger, 1990)

Below is a visualization of Peirce's conception of the relationship between different kinds of signs:

\begin{tabular}{|llll|}
\hline & Icons & Indexes & Symbols \\
\hline Signify by: & Resemblance & Cause and effect & Convention \\
Example: & Commercial & Gravity and falling & Stop sign \\
Process: & Can see & Can figure out & Must learn \\
\hline
\end{tabular}

Van Leeuwen (1996) proposed that composition related the representational and interactive meanings of the picture or multimodal "text" to each other through three interrelated systems:

(1) Information value. The placement of elements (participants and syntagms that relate them to each other and to the viewer) endows them with the specific information values attached to the various "zones" of the image: left and right, top and bottom, centre and margin.

(2) Salience. The elements (participants and representational and interactive syntagms) are made to attract the viewer's attention to different degrees, as realized by such factors as placement in the foreground or background, relative size, contrasts in tonal value (or color), differences in sharpness, etc. 
(3) Framing. The presence or absence of framing devices (realized by elements which create dividing lines, or by actual frame lines) disconnects or connects elements of the image, signifying that they belong or do not belong together in some sense.

Kress and Van Leeuwen stated that if a text is multimodal it should be analyzed in an integrated way (Van Leeuwen, 183). Super Bowl commercials utilize the system of salience to a great degree; in the "Mr. Sandman" Super Bowl commercial the ad firm decided to use a sensuous model to "initiate" the forward thrust of the Kia Motors car. The female figure has cultural salience, "thus the advertisement gives greater stress to the promise of the product than to the factual information it also offers" (Kress, \& Van Leeuwen, 1996).

RQ 1: What differences, if any, are there between the symbols and visual rhetoric or strategies used during Super Bowl commercials during a recession year versus what they are like during a non-recession year? Recession here is defined as a period of temporary economic decline. GDP changes as total output and/or prices change. A rise in total output means that an economy is growing; two consecutive quarters of decline in total output is the technical definition of recession (Hutchinson, 2010). The methods of content analysis and semiotic analysis will be used to address the research question.

H1: The hypothesis presented in this paper was that there will be more humorous commercials during a recession. 


\section{METHODS}

There are several reasons for why a dual approach has been chosen for this study. Because it comes from a literary criticism tradition, semiotic analyses are basically interpretive. While it is a good way to analyze individual advertisements, it cannot systematically address a large number of ads. Size of data, reliability, and generalizability can only be addressed with the approach of content analysis.

Content analysis is "a research method that uses a set of procedures to make valid inferences from text" (Weber, 1990). This type of analysis can be used for many purposes, including:

- reflecting cultural patterns of groups, institutions, or an entire society;

- revealing the focus of groups, institutions, or a society; and

- identifying and describe the trends in communication content.

One of the central ideas in content analysis is that many "words" of the "text" are classified into much fewer content categories. Words, phrases or concepts in the same category are assumed to have meanings that are similar. This similarity can be based on the precise meanings of words (which could group synonyms together) or words sharing the same connotation (like words implying the concept of truth or beauty). The 
classification procedure in a content analysis must be consistent- coders must code the "text" in the same way.

Content analysis has been used to study many things, including popular art forms. Walker (1975) analyzed similarities and differences in the music of popular songs by American black and white musicians. Walker used computer analysis software to investigate differences in narrative form. Compared to white popular music, "rhythm and blues" and "soul" song lyrics "showed greater emphasis on action in the objective world, less concern with time, and greater emphasis on what Walker calls "tough mindedness" or "existential concreteness." In addition to narrative form Walker also addressed narrative focus. He found that identification with others "increased significantly over time in "soul" and "rhythm and blues" lyrics, but not in popular white song lyrics" (Weber, 1990). Narrative form will be addressed in this Super Bowl analysis, and the idea of taking a sign and discerning the concept behind it and then classifying the results is one takeaway from the Walker study that will be beneficial to the analysis of Super Bowl commercials. For instance in the Walker study, lyrics using the concept of strength could equal "tough-mindedness."

In another study, Aries (1973) studied differences involving female, male, and mixed-sex groups, (i.e. sex-role socialization). When females were in a group alone, they would show concern with interpersonal issues. Women discussed "themselves, their homes and families, and their relationships, defining themselves by the way they relate to the significant others who surround them" (Weber, 1990). Men, on the other hand, 
"indirectly related personal experiences and feelings through stories and metaphors" (Weber, 1990). However in the mixed group women talked less of their families. They oriented "themselves around being women with men by assuming the traditional female role" (Weber, 1990). This study demonstrated that a content analysis can be used to study small groups as microcosms of society.

Lowry (2010) studied how Western images are constructed in Chinese magazine advertising. One of the conclusions was that when Western models were used in Chinese ads, they served different roles than Chinese models. These roles were classified according to the categories set out by the researcher. Lowry first describes the history of Orientalism and Occidentalism in advertising and marketing. He used nine categories, relating to various aspects of ads. The categories were extensive- the "product type" unit had 23 variables. The categories included in Lowry's study were product and service, brand origin, Western settings, occupational status, levels of nudity/ sex appeal, subordination, perceived importance, relation to product, and model race and country of origin. Unlike Lowry's study, this study will only require four variables for "product type," as Super Bowl commercials are dominated by large industries. In the Lowry paper, $5 \%$ of the ads were randomly selected for coding by another individual, and Cohen's Kappa was calculated for the different variables. In the semiotic analysis that followed Lowry used the content analysis to determine which ads to analyze semiotically. The decoding of images of the West in Chinese magazine advertising drew on Lowry's knowledge of sign relationships based on the scholarship, Western symbols, and cultural conventions in China. Lowry's study approached the problem of how Western images are 
constructed in Chinese magazine advertising using both content analysis and semiotic analysis. Both of these approaches are qualitative; they rely less on statistical, numerical data and more on interpretive data.

This thesis addressed the research question through a content analysis involving several variables as well as semiotic analyses of the content. Signs and sign processes (semiosis) are the variables in this study. Sign is defined as a thing that represents or stands for something else, especially a material object representing something abstract. For example, a limousine is a symbol of wealth and authority.

The difference between qualitative research and quantitative research was fundamental to understanding the way data is collected and analyzed in this paper. Qualitative content analysis is a method for systematically describing the meaning of qualitative material. This is accomplished by classifying material as instances of the categories of a coding frame (Schreier, 2012). Qualitative content analysis is useful when there is a degree of interpretation in arriving at the meaning of data. Meaning is not a given; meaning is constructed by the recipient of the message. If a researcher is dealing with highly standardized meanings, there is no need for qualitative content analysis (Schreier, 2012). For instance, if a researcher wanted to determine the hair color of news anchors: this requires little interpretation, so quantitative content analysis would be better suited. Qualitative content analysis would be better suited when meaning is less obvious. Meaning is not always manifest in the initial analysis. It is sometimes best to read text or images in greater detail to determine what it means. Quantitative research deals with 
numerical information, and it does not leave very much room for interpretation for what, for instance, a "10" means or a " $500 "$. Qualitative research deals with symbolic materialverbal and visual data that leaves room for interpretation. It is not always possible to pin down an objective meaning of symbolic material, nor do qualitative researchers intend to.

The process of interpreting meaning is a process of one's own background, so an objective meaning of any piece of data loses its appeal (Schreier, 2012). One key distinction between qualitative content analysis and other types of qualitative research is that it requires the researcher to decide on one out of a multiplicity of meanings. Key features of qualitative research are that it is: interpretive, naturalistic, situational, reflexive, has emergent flexibility, inductive, case-oriented, and puts emphasis on validity. There is an important distinction between a dictionary-based (quantitative) approach and a qualitative approach. A dictionary-based approach creates a group of categories that are derived from the frequency list of words and control the allocation of words and their respective categories over the texts. While methods in quantitative content analysis in this way transform observations of found categories into quantitative statistical data, the qualitative content analysis focuses more on the intentionality and its implications.

Semiotic analysis and qualitative content analysis can be combined, as they share the goal of describing denotative, literal meaning. Although they are both concerned with the description of denotative meaning, semiotics goes more in-depth and focuses more on the individual case. Semiotics is also different in that agreement between the group of 
researchers is not a criterion for evaluating the analysis, and allows one to explore connotative, figurative, culturally ascribed meanings. Semiotics and qualitative analysis can be combined in one of two ways: by using qualitative content analysis to describe the denotative meaning of the data, and by turning certain semiotic categories into qualitative content analysis categories and classifying the material accordingly (Schreier, 2012).

\section{RESULTS}

The subsequent material provides both a content analysis and semiotic analysis of a selection of Super Bowl commercials from each year between 2009 and 2012.

\section{CONTENT ANALYSIS}

\section{Sampling Methods Procedure}

In order to provide a comprehensive and updated view of the symbols or strategies used in Super Bowl commercials during recession and non-recession years, this study attempted to capture the true diversity of the symbolic content, hence there are six types of product. At the first stage, the sampling frame (the four most recent years February 2009-2012) was decided. Second, a random sample of commercials was chosen for analysis. Since the purpose of the study was to examine symbols that the average Super Bowl commercial viewer is exposed to, this study included Food, Beverage, Automobile, Technology, Service Industry, and Entertainment products. 
The author coded all 40 advertisements for the content analysis. The second coder was a fourth-year WVU geography student in her early 20 s. She was very familiar with the Super Bowl and its commercials. About two hours of training session and discussion was conducted.

Using Cohen's Kappa, the intercoder reliability was as follows: 1 for tone, 1 for product references, .86 for celebrity inclusion, 1 for product type, and .69 for general symbols.

\section{Product Type}

Table 1.1 displays the entire line of products, their makers, and the number of times they were featured in the group of Super Bowl commercials under analysis.

(Table 1.1).

Table 1.1.

Sample Overview: Frequency of Broadcast 2009-2012 by company name

\begin{tabular}{|l|l|l|l|}
\hline Company Name & Product & $\begin{array}{l}\text { Broadcast } \\
\text { Frequency }\end{array}$ & Years \\
\hline Hulu & Hulu Plus & 1 & 2009 \\
\hline Coca Cola & Coke & 2 & 2009,2011 \\
\hline Bridgestone & Tires & 1 & 2009 \\
\hline Budweiser & Bud Light & 3 & $2009,2011,2012$ \\
\hline Audi & Audi Car & 3 & $2009,2010,2012$ \\
\hline GE & Smart Grid Technology & 1 & 2009 \\
\hline Career Builder & Job Services & 1 & 2009 \\
\hline Pepsi & Pepsi Max & 1 & 2009 \\
\hline NBC & Heroes Television Show & 1 & 2009 \\
\hline Sobe & Sobelieve Lifewater & 1 & 2009 \\
\hline Google & Search Engine & 1 & 2010 \\
\hline Snickers & Snickers Candy Bar & 1 & 2010 \\
\hline Kia & Sorento, Optima & 2 & 2010,2012 \\
\hline Volkswagen & Beetle & 2 & 2010,2011 \\
\hline
\end{tabular}




\begin{tabular}{|l|l|l|l|}
\hline Motorola & Xoom & 2 & 2010,2011 \\
\hline E-Trade & Online Stock Brokerage & 1 & 2010 \\
\hline Dr. Pepper & Dr. Pepper & 1 & 2010 \\
\hline Doritos & Doritos Chips & 1 & 2010 \\
\hline Hyundai & Sonata & 1 & 2010 \\
\hline Chrysler & Chrysler 200 & 2 & 2011,2012 \\
\hline Teleflora & Online Florist Service & 1 & 2011 \\
\hline Chevrolet & Cruze, Camaro & 3 & 2011,2012 \\
\hline Best Buy & Electronics Service Store & 1 & 2011 \\
\hline M\&M & M\&Ms & 1 & 2012 \\
\hline Toyota & Camry & 1 & 2012 \\
\hline Samsung & Galaxy Note & 1 & 2012 \\
\hline FIAT & 500 Abarth & 1 & 2012 \\
\hline Acura & NSX & 1 & 2012 \\
\hline
\end{tabular}

\section{Variability of Symbols}

RQ1 asked about the change or lack of change of the symbols during recession and nonrecession years. Table 1.2 showed that during recession years (2009 and 2011), among the 40 advertisements, 10\% used Sports Props, 35\% used Automobiles, 20\% used Attractive Women, 20\% used Animals, and 15\% were classified as Not Applicable in recession years. It also showed that $15 \%$ used Sports Props, 45\% used Automobiles, 20\% used Attractive Women, 5\% used Animals, and 15\% were classified as Not Applicable in non-recession years (2010 and 2012).

(Table 1.2).

Table 1.2.

Overview of variability of symbols used from 2009-2012

Sports Props Automobiles Attractive Animals N/A

Women

2009

$3(30 \%)$

$1(10 \%) \quad 3(30 \%)$

$2(20 \%)$ 
2010

$$
2(20 \%)
$$

$3(30 \%)$

$2(20 \%)$

$0(0 \%)$

$3(30 \%)$

2011

$$
1(10 \%)
$$

$4(40 \%)$

$3(30 \%)$

$1(10 \%)$

$1(10 \%)$

2012

$1(10 \%)$

$6(60 \%)$

$2(20 \%)$

$1(10 \%)$

$0(0 \%)$

$\mathrm{H} 1$ theorized that during a downturn advertising agencies may resort to humor to sell their products. Table 1.3 showed that during recessions $75 \%$ of commercials were humorous and during non-recession years $90 \%$ of commercials were humorous.

(Table 1.3).

Table 1.3.

Percentage of Humorous commercials

$\begin{array}{lll}\text { Year } & \text { Recession or non-recession } & \begin{array}{l}\text { Frequency of Humorous } \\ \text { commercials }\end{array} \\ 2009 & \text { Recession } & 7(70 \%) \\ 2010 & \text { Non-Recession } & 9(90 \%) \\ 2011 & \text { Recession } & 8(80 \%) \\ 2012 & \text { Non-Recession } & 9(90 \%)\end{array}$

Another interesting result of the content analysis was the emergence of a consistent pattern in actor response to the products. Two of the main responses that occurred over and over were refreshment/satisfaction and loss/disappointment. Table 1.4 showed that $25 \%$ of recession commercials were refreshment/satisfaction and $15 \%$ were

loss/disappointment, while $15 \%$ of non-recession commercials were refreshment/satisfaction and 5\% were loss/disappointment.

(Table 1.4)

Table 1.4 
Actor Response Patterns

Actor Response

Recession NonFrequency

Recession

Percentage out

Frequency

Satisfaction/Refreshment 5

Loss/Disappointment 3

3

of Total

Commercials

$20 \%$

$1 \quad 10 \%$

\section{Crosstabulation of Recession Years and Categories}

Recession X Tone

The Pearson chi-square test of independence was computed to determine if there was a significant relationship between recession years (09-10 and 11-12) and tone of advertisement. The analysis indicated that there was not a significant relationship, $\mathrm{X}^{2}(2$, $\mathrm{N}=40)=.36, \mathrm{p}>.05$. There were no significant differences in tone used in advertisements between recession and non-recession years.

Crosstabulation of Recession Years and Advertising Tone

\begin{tabular}{|c|c|c|c|c|c|c|}
\hline & & & \multicolumn{3}{|c|}{ Tone } & \multirow[b]{2}{*}{ Total } \\
\hline & & & Humor & Serious & Cool & \\
\hline \multirow[t]{10}{*}{ Recession } & \multirow[t]{5}{*}{$09-10$} & Count & 16 & 2 & 2 & 20 \\
\hline & & Expected Count & 16.5 & 2.0 & 1.5 & 20.0 \\
\hline & & $\%$ within Recession & $80.0 \%$ & $10.0 \%$ & $10.0 \%$ & $100.0 \%$ \\
\hline & & $\%$ within Tone & $48.5 \%$ & $50.0 \%$ & $66.7 \%$ & $50.0 \%$ \\
\hline & & $\%$ of Total & $40.0 \%$ & $5.0 \%$ & $5.0 \%$ & $50.0 \%$ \\
\hline & \multirow[t]{5}{*}{$11-12$} & Count & 17 & 2 & 1 & 20 \\
\hline & & Expected Count & 16.5 & 2.0 & 1.5 & 20.0 \\
\hline & & $\%$ within Recession & $85.0 \%$ & $10.0 \%$ & $5.0 \%$ & $100.0 \%$ \\
\hline & & $\%$ within Tone & $51.5 \%$ & $50.0 \%$ & $33.3 \%$ & $50.0 \%$ \\
\hline & & $\%$ of Total & $42.5 \%$ & $5.0 \%$ & $2.5 \%$ & $50.0 \%$ \\
\hline Total & & Count & 33 & 4 & 3 & 40 \\
\hline
\end{tabular}




\begin{tabular}{|l|r|r|r|r|}
\hline Expected Count & 33.0 & 4.0 & 3.0 & 40.0 \\
\% within Recession & $82.5 \%$ & $10.0 \%$ & $7.5 \%$ & $100.0 \%$ \\
\% within Tone & $100.0 \%$ & $100.0 \%$ & $100.0 \%$ & $100.0 \%$ \\
\% of Total & $82.5 \%$ & $10.0 \%$ & $7.5 \%$ & $100.0 \%$ \\
\hline
\end{tabular}

Recession X Product

The Pearson chi-square was computed to determine if there was a significant relationship between recession years (09-10 and 11-12) and product in advertisement. The analysis indicated that there was not a significant relationship, $\mathrm{X}^{2}(5, \mathrm{~N}=40)=.53, \mathrm{p}>.05$. There were no significant differences in products used in advertisements between recession and non-recession years.

Crosstabulation of Recession Years and Advertising Products

\begin{tabular}{|c|c|c|c|c|c|c|}
\hline & & & \multicolumn{3}{|c|}{ Product References } & \multirow[b]{2}{*}{ Total } \\
\hline & & & $\begin{array}{c}1 \\
\text { reference }\end{array}$ & $\begin{array}{c}2 \\
\text { references }\end{array}$ & $\begin{array}{c}3 \text { or more } \\
\text { refs }\end{array}$ & \\
\hline \multirow[t]{10}{*}{ Recession } & $09-10$ & Count & 2 & 7 & 11 & 20 \\
\hline & & Expected Count & 1.0 & 5.0 & 14.0 & 20.0 \\
\hline & & $\%$ within Recession & $10.0 \%$ & $35.0 \%$ & $55.0 \%$ & $100.0 \%$ \\
\hline & & $\begin{array}{l}\text { \% within Product } \\
\text { References }\end{array}$ & $100.0 \%$ & $70.0 \%$ & $39.3 \%$ & $50.0 \%$ \\
\hline & & $\%$ of Total & $5.0 \%$ & $17.5 \%$ & $27.5 \%$ & $50.0 \%$ \\
\hline & $11-12$ & Count & 0 & 3 & 17 & 20 \\
\hline & & Expected Count & 1.0 & 5.0 & 14.0 & 20.0 \\
\hline & & $\%$ within Recession & $.0 \%$ & $15.0 \%$ & $85.0 \%$ & $100.0 \%$ \\
\hline & & $\begin{array}{l}\% \text { within Product } \\
\text { References }\end{array}$ & $.0 \%$ & $30.0 \%$ & $60.7 \%$ & $50.0 \%$ \\
\hline & & $\%$ of Total & $.0 \%$ & $7.5 \%$ & $42.5 \%$ & $50.0 \%$ \\
\hline Total & & Count & 2 & 10 & 28 & 40 \\
\hline
\end{tabular}




\begin{tabular}{|l|r|r|r|r|}
\hline Expected Count & 2.0 & 10.0 & 28.0 & 40.0 \\
\% within Recession & $5.0 \%$ & $25.0 \%$ & $70.0 \%$ & $100.0 \%$ \\
\% within Product & $100.0 \%$ & $100.0 \%$ & $100.0 \%$ & $100.0 \%$ \\
References & & & & \\
\% of Total & $5.0 \%$ & $25.0 \%$ & $70.0 \%$ & $100.0 \%$ \\
\hline
\end{tabular}

Recession X Symbols

The Pearson chi-square was computed to determine if there was a significant relationship between recession years (09-10 and 11-12) and symbols uses in advertisement. The analysis indicated that there was not a significant relationship, $\mathrm{X}^{2}(4, \mathrm{~N}=40)=.22, \mathrm{p}>.05$. There were no significant differences in symbols used in advertisements between recession and non-recession years.

Crosstabulation of Recession Years and Advertising Symbols

\begin{tabular}{|c|c|c|c|c|c|c|c|c|c|}
\hline & \multicolumn{6}{|c|}{ Product Type } & \multirow[b]{2}{*}{ Total } \\
\hline & & & \multirow{2}{*}{$\frac{\text { Food }}{2}$} & \multirow{2}{*}{$\begin{array}{c}\begin{array}{c}\text { Beverag } \\
\mathrm{e}\end{array} \\
5\end{array}$} & \multirow{2}{*}{\begin{tabular}{|l} 
Auto \\
6
\end{tabular}} & \multirow{2}{*}{$\frac{\text { Tech }}{3}$} & $\begin{array}{c}\text { Servic } \\
\mathrm{e} \\
\end{array}$ & $\begin{array}{c}\text { Entertai } \\
\mathrm{n}\end{array}$ & \\
\hline \multirow{6}{*}{$\begin{array}{l}\text { Recessio } \\
\mathrm{n}\end{array}$} & 09 & Count & & & & & 2 & 2 & 20 \\
\hline & & $\begin{array}{l}\text { Expected } \\
\text { Count }\end{array}$ & 1.5 & 4.5 & 8.5 & 2.5 & 2.0 & 1.0 & 20.0 \\
\hline & & $\begin{array}{l}\% \text { within } \\
\text { Recessio } \\
n\end{array}$ & $10.0 \%$ & $25.0 \%$ & $30.0 \%$ & $15.0 \%$ & $10.0 \%$ & $10.0 \%$ & $\begin{array}{r}100.0 \\
\%\end{array}$ \\
\hline & & $\begin{array}{l}\% \text { within } \\
\text { Product } \\
\text { Type }\end{array}$ & $66.7 \%$ & $55.6 \%$ & $35.3 \%$ & $60.0 \%$ & $50.0 \%$ & $100.0 \%$ & $50.0 \%$ \\
\hline & & $\begin{array}{l}\% \text { of } \\
\text { Total }\end{array}$ & $5.0 \%$ & $12.5 \%$ & $15.0 \%$ & $7.5 \%$ & $5.0 \%$ & $5.0 \%$ & $50.0 \%$ \\
\hline & 11 & Count & 1 & 4 & 11 & 2 & 2 & 0 & 20 \\
\hline
\end{tabular}




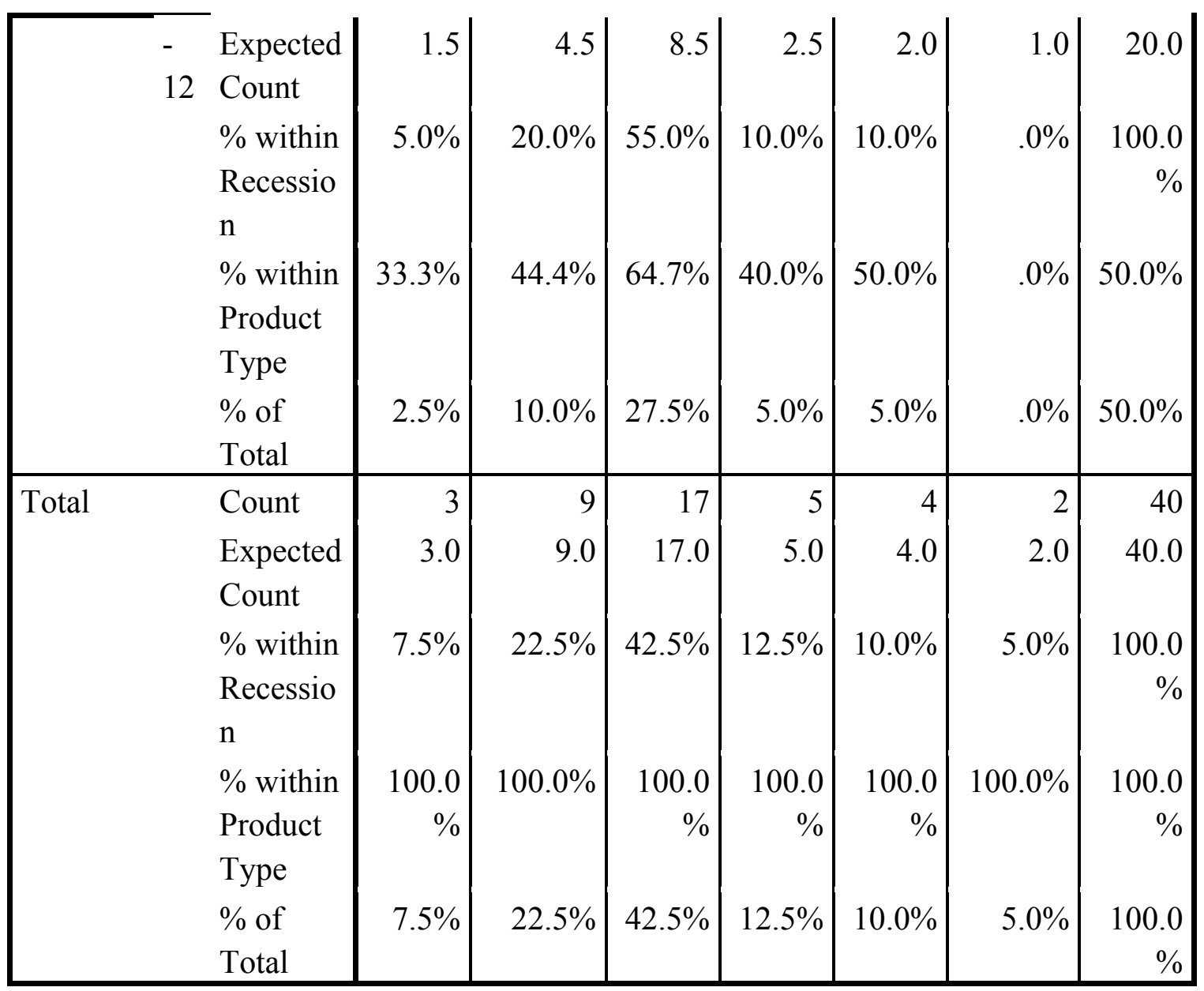

\section{Recession X Celebrity}

The phi correlation was computer to determine the relationship between recession years (09-10 and 11-12) and whether a celebrity was used in the advertisement. The analysis indicated that there was not a significant relationship, $\mathrm{r}_{\ominus}(38)=.00, \mathrm{p}>.05$. There were no significant differences in celebrities used in advertisements between recession and nonrecession years.

Correlation for Recession Years with Celebrity Inclusion

Correlations

Recession $\quad$ Celebrity




\begin{tabular}{|ll|r|r|}
\hline Recession & Pearson Correlation & 1 & .000 \\
& Sig. (2-tailed) & & 1.000 \\
& $\mathrm{~N}$ & 40 & 40 \\
\hline Celebrity & Pearson Correlation & .000 & 1 \\
& Sig. (2-tailed) & 1.000 & \\
& $\mathrm{~N}$ & 40 & 40 \\
\hline
\end{tabular}

SEMIOTIC ANALYSIS

\section{Semiotic Procedure}

In the semiotic analysis section, individually selected commercials were chosen to be analyzed using semiotics. While the content analysis concentrated on individual variables, such as tone, frequency and symbols, the semiotic analysis handled every commercial as an aggregate, and then analyzed those variables together within a given commercial. Some of the commercials were selected because they exemplify categories that were predominant in the conclusion of the content analysis, and some commercials were chosen because they better represent ideas not covered through the process of content analysis.

In this study, interpretation of the elements of commercials derives from the author's understanding of scholar's pursuits in the development of the connections between signs, cultural symbols, American cultural systems, and connections between images in commercials and images in other media. The author analyzed both the connection 
between essential features within the commercials, and their allusions external to the commercials.

\section{Celebrity Culture in Commercials}

Going through commercials of the 2012 Super Bowl, $80 \%$ of the commercials that included celebrities advertised automobiles, cars specifically. Of those, $40 \%$ had a frequency of two shots where the product was clearly visible or mentioned. Those commercials strongly featured their respective celebrity, almost to the exclusion of the product itself. One of these commercials is "Halftime in America," and it is a representative of what a popular Super Bowl commercial can achieve. The official YouTube video has over 11.5 million hits alone. It is also a good representative of how a commercial can more directly reference the economic climate of the U.S. through dialogue, image and symbol. Although it was broadcast during a non-recession year, the anxiety the commercial evokes is permeated with a feeling of hope.

\section{Halftime in America}




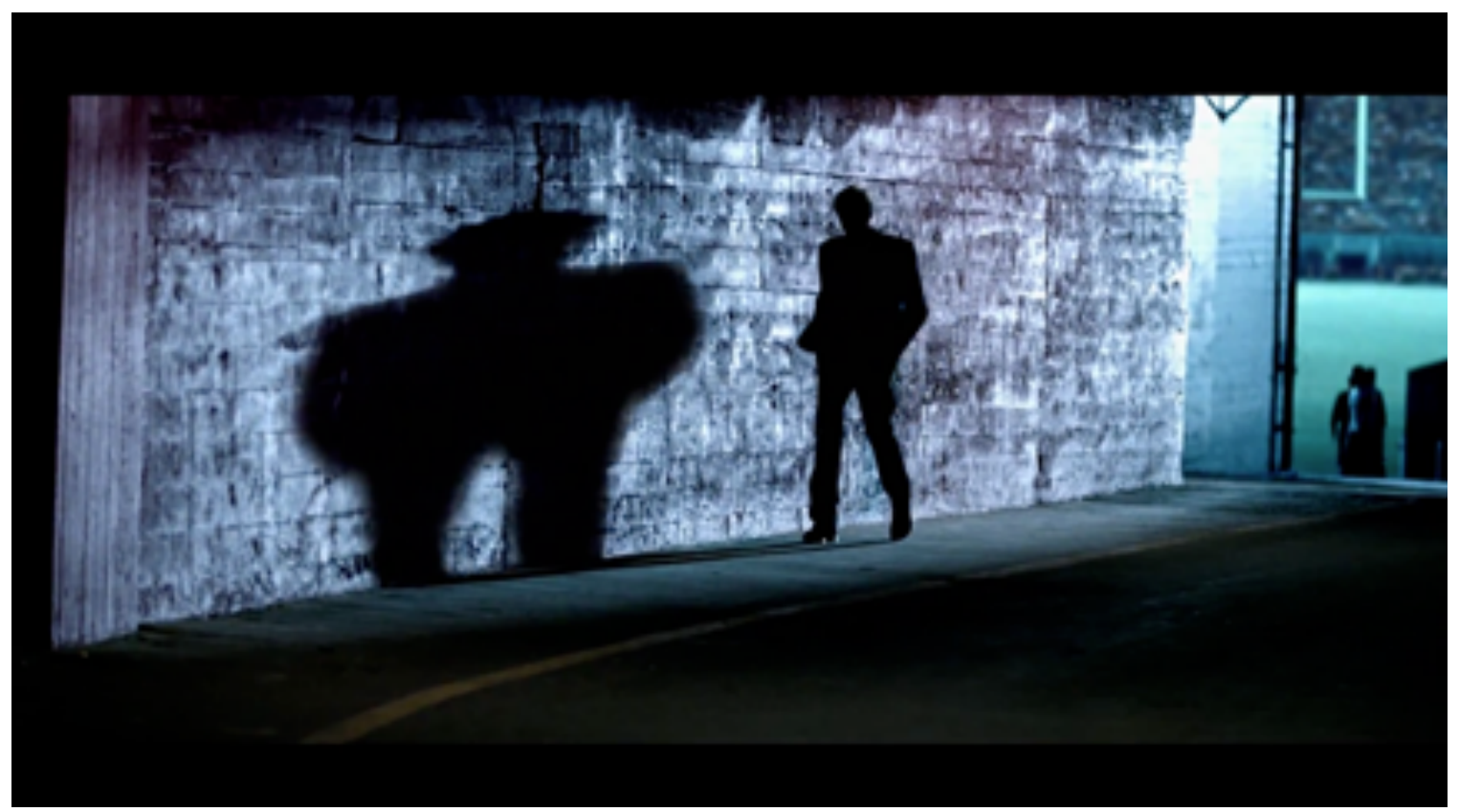

Figure 1. Eastwood casts a large shadow. Copyright Chrysler.

Clint Eastwood, as a symbol, is a cultural production. The 2012 commercial (nonrecession year) Halftime in America is an example of the celebrity symbol. A celebrity is a person who has earned fame as a result of a particular action or perceived quality and is then celebrated (Stearns, 2008). Once relegated to royalty, fame and celebrity grew in the 18th and 19th centuries, in the background of the print revolution (Stearns, 2008). On the other hand, television and movie stars are understood to be "Hollywood Royalty" (Stearns, 2008). Clint Eastwood is not, as Daniel Boorstin might say a "human pseudoevent;" Eastwood is courageous, daring, and meaningful. In Halftime, the product (a car) is the signified, implied by the signifier, Clint Eastwood (with whom the car industry wants to identify itself).

Regarding his craft, Eastwood stated that "acting is more than ranting, raving, crying and rolling around on the ground" (Smith, 1997, p. 207). Adding to his masculine mystique is his well-known fitness routine. His is a body "that at least appears to be both powerful 
enough to be indestructible and experienced and at the same time ordinary enough to be able to disappear" (Smith, 2007, p. 207).

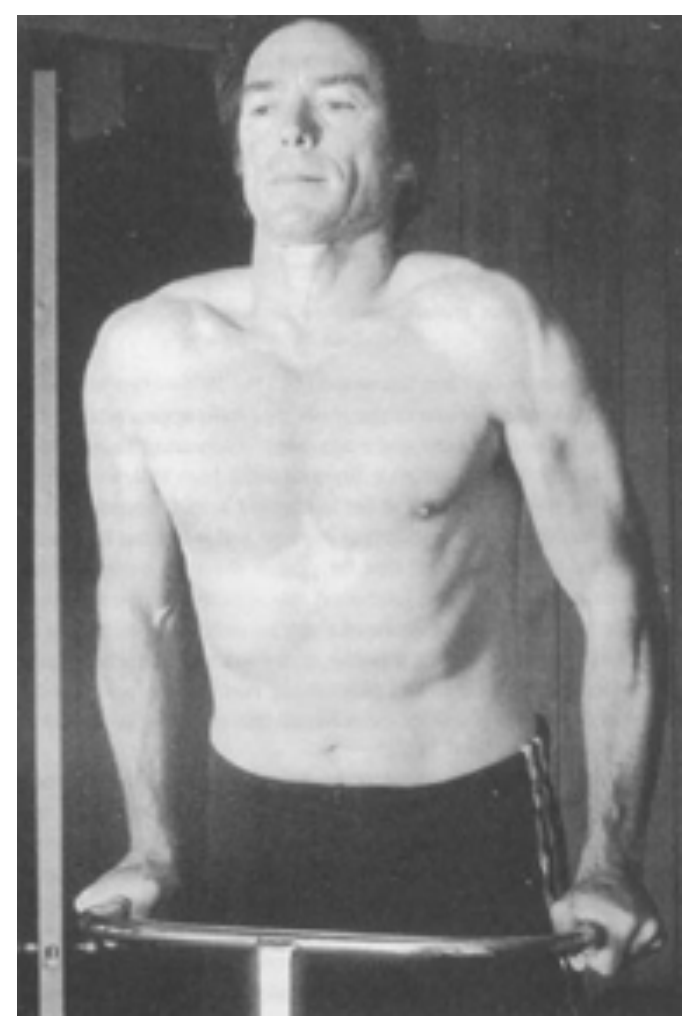

Figure 2. Sculpting the Physique. Copyright Paul Smith, 2007.

This controlling narrative of strength and fallibility plays out through the course of the commercial. Like Eastwood facing his age, Detroit is braving the hardships of an economic downturn. It is thus understood that, through association, Detroit possesses the positive qualities of Eastwood's intense, enduring personality. As Eastwood says, "they almost lost everything."

Iconoclast. Rebel. Director. Not content to reside in front of the camera, Eastwood garnered critical acclaim in his 1979 collaboration with Siegel, Escape From Alcatraz (Smith, 2007). The title of auteur came to him in the mid-1980's in articles like the one in The Los Angeles Times entitled "Auteurity Figure at the Helm” (18 May, 1985) (Smith, 
2007). Eastwood's movies provide a wealth of material for conceptualizing sexuality and power in commercial-making today. In a famous Annie Lebowitz photo Eastwood is shown emerging from a dust cloud, hogtied with an upturned lip and the same intense gaze exhibited in Halftime in America.
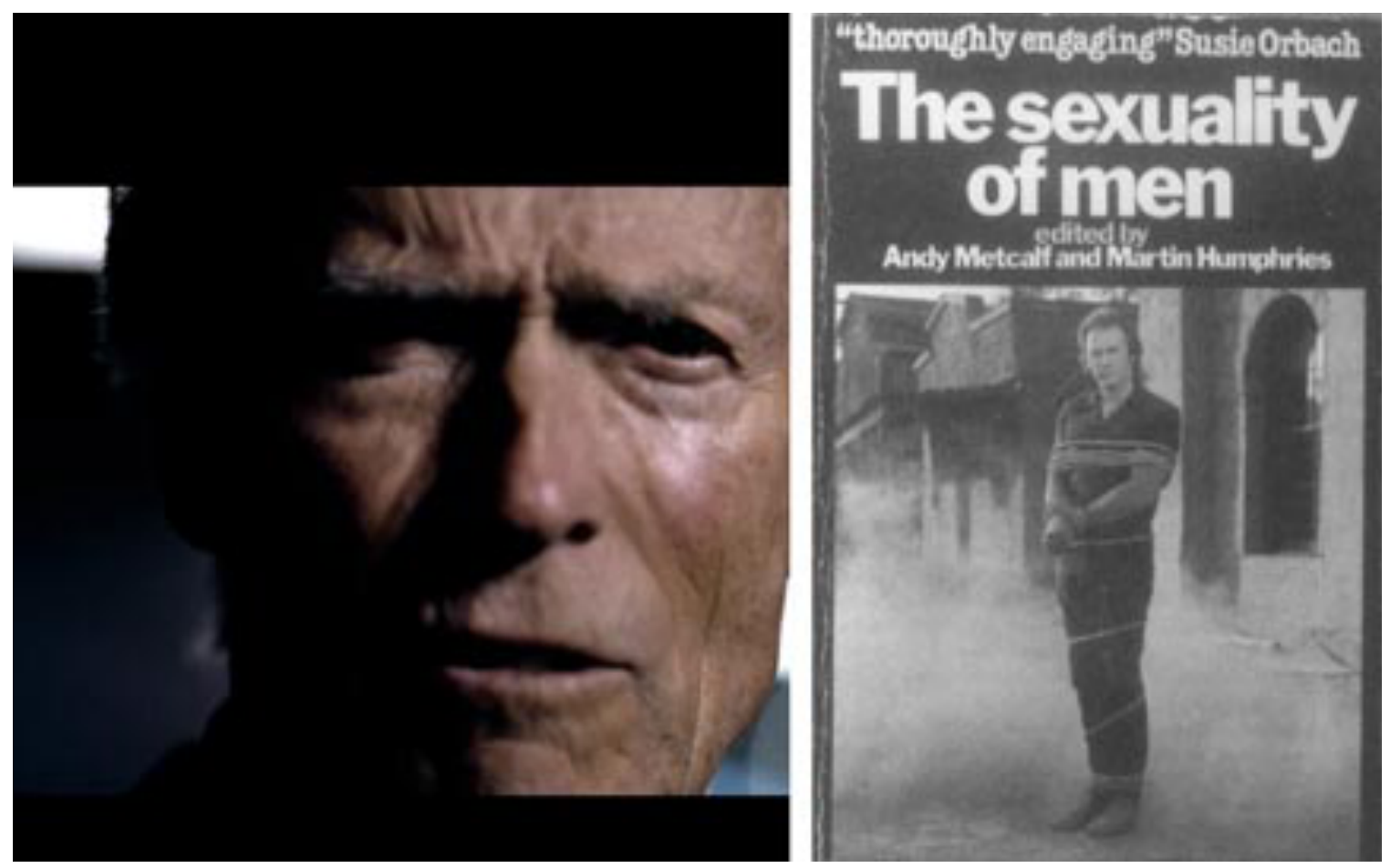

Figure 3. Split-screen of the fervent gaze. Copyright Chrysler \& Pluto Press.

The Lebowitz image is a symbolic embodiment of suppressed sexuality. It has been asserted that there is a homoerotic underside to Eastwood's tough, macho-man exterior (Neale, 1993). Through his films the audience can vicariously participate in sadism and voyeurism he encounters. In Masculinity as Spectacle, Steve Neale (1993) suggested that the male body cannot be eroticized by another male but "that look must be motivated in some other way, its erotic component repressed. The mutilation and sadism so often involved are marks both of the repression involved and of a means by which the male 
body may be disqualified, so to speak, as an object of erotic contemplation and desire" ( $\mathrm{p}$. 7). The way latent homoeroticism operates in his films can be superimposed on the way his machismo functions as a homoerotic display of suppressed masculinity in Halftime in America. For it was not through his actions but through his attitude that he conveys his masculinity. When he says 'We'll find a way through tough times, and if we can't find one we'll make one," the machismo Eastwood symbolizes has a comforting effect on the viewer, as Chrysler not only sought to boost their following but also to pacify the viewer.

\section{THE THRILL OF THE CHASE AND RISE OF THE PHALLUS}

The following two commercials were chosen because they share the same tone, product type, and actor response (Cool, Automobile, and Fulfillment). Adding to the similarities, they also have a high frequency of product references relative to the other commercials analyzed. Because the commercials are in part about the way the car drives, the car is visually referenced many times from different perspectives. Also, they were partially selected for their reflection of the recession theme, as they were both broadcast during downturns. 


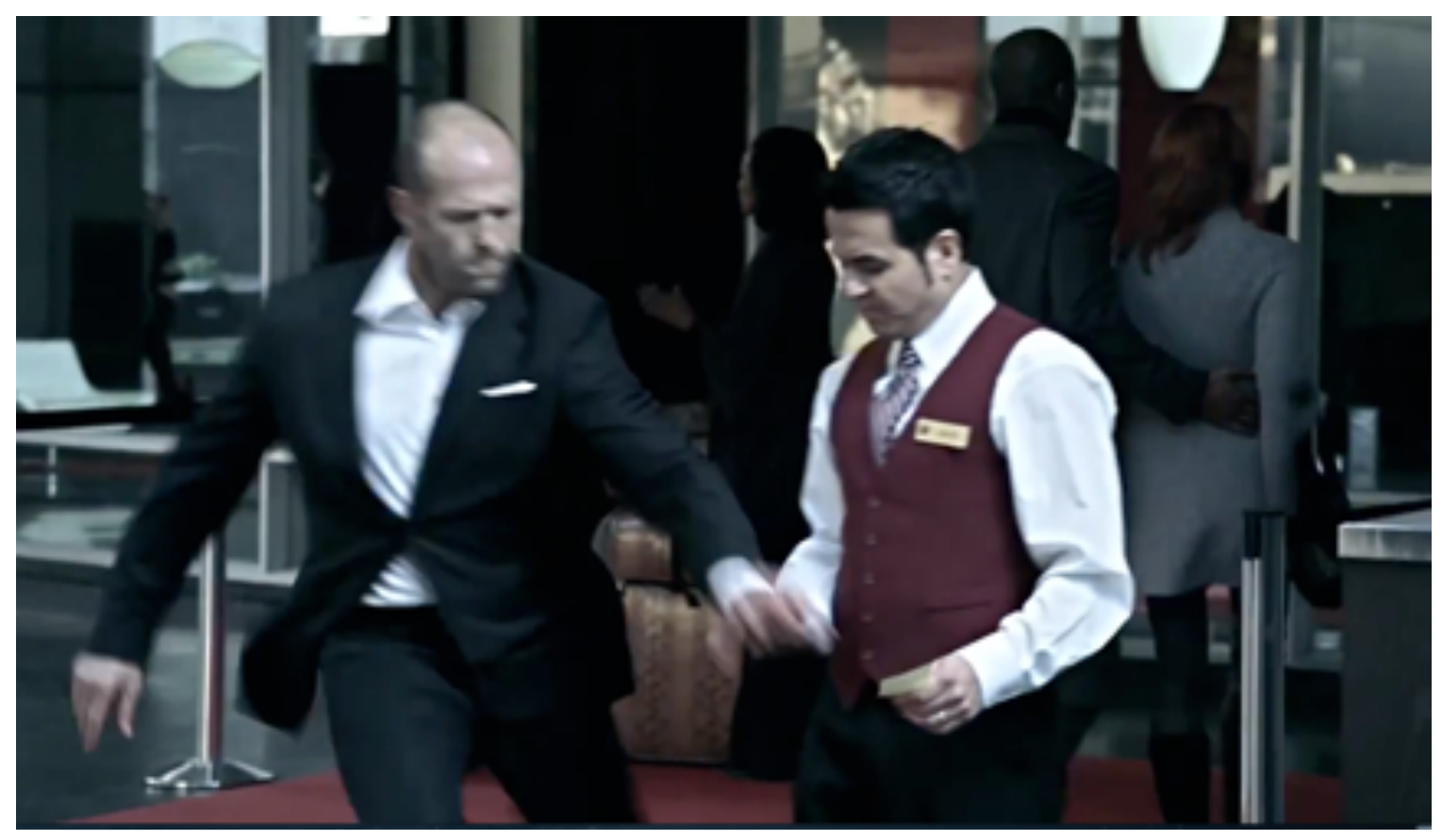

Figure 4. Statham carjacking a valet. Copyright Volkswagen Group.

It is common knowledge to many an action movie junkie that no Hollywood actionadventure is complete without the classic car chase (Eisenstein, 1991). In the 2009 (recession year) Audi commercial, Jason Statham, a symbol of masculinity and excitement, jumps through a first-story window leaving a wake of sirens and cascading glass. Statham proceeds to carjack a Mercedes in a 70's-style period piece, a nostalgic recreation. Each competitor's car is featured in an earlier decade and carjacked, from the 70's up to the present, where the Audi not only inhabits and dominates the neo-cool aesthetic (it having a cool tone) but also the $21^{\text {st }}$ century.

While driving the BMW Statham drives the car off a concrete embankment into a large billboard advertising "Miami Mousse," which assures us that "The Mousse is Loose." Beyond the symbolic consequences of an action star tearing through a woman's hygiene product like a linebacker through a breakaway banner, this event highlights the ludicrous 
improbability of action movie stunts. This commercial is foreshadowed by the film Transporter 2 (during which Statham also drives an Audi), wherein Statham deftly disables a bomb on the bottom of his car by tapping a jump ramp, spinning the car, and dislodging the bomb on the crane of an adjacent truck. Statham films have a vertiginous style with dizzying aerial shots, upside-down angles, time-lapse photography, slo-mo shots, and sleek yet hollow visuals (Fleming, 2005). Through the usage of period set pieces and disorienting visuals the automakers sought to portray the Audi as hip, cool, current, and as an artistic and engineering miracle.

\section{MISS EVELYN}

Miss Evelyn (2011, recession year) is another example of the car chase genre of commercial advertisement. Two friends are visualizing their fantasies through the lens of a Camaro commercial. The Camaro begins dodging monolithic mirrors in an arid desert, and as the fantasy continues, what transpires is the characteristic male heterosexual expression that often occurs in Super Bowl commercials. The two buddies envision what type of attractive woman would be driving the Camaro (it could not be a male driver as this is a heterosexual daydream). "Maybe it's a woman that's driving." "Hot." "Totally." "She's blond." "Redhead." "Or a Redhead." The first driver is Caucasian with long brunette hair, followed by an Asian woman with short chin-length black hair, then a blond haired woman with long flowing curly locks, and finally a femme fatale with tiedback velvet-red hair and bright red lipstick. What follows is a chase scene reminiscent of the Audi commercial with Statham. What is surprising is not that both commercials 
feature a car and motorcycle chase with black trucks and motorcyclists, but that all of the motorcyclists wore black leather with black helmet and black bikes.

The operation of the motorcyclist symbol in relation to masculinity is an important variable for understanding the intentions of the automaker (whether they advocate or intentionally understand the effects of their decisions is debatable). Motorcycles are:

distinctly masculine. The motorcycle can be seen as a phallic object (evidenced by its nickname, crotch rocket) that represents the rider's sexuality and potency, a real and metaphorical power that attracts both men and women to bike as well as rider. In addition, the leather clothing worn as a protective necessity has sexual connotations because of its natural connection to animal primacy and its cultural association with sadomasochistic sexual practices. Within gay male culture, leather outfits such as those worn by motorcyclists are worn by some men to emphasize their masculinity and sexuality. Leather also distinguishes its wearers as adhering to a set of social and/or sexual codes outside the norm. (Veenstra, 2007, p. 1039)

Although women are becoming increasingly integrated into the motorcycling culture, they still tend to be passengers on the bikes of men (Veenstra, 2007). This all seems to unearth a psychological recess in the minds of men that Super Bowl commercials address regarding the suppression of homoerotic expression. Perhaps the more anti-homosexual you zealously pronounce yourself to be, the more hidden are your insecurities toward acknowledging the ambiguous nature of human sexuality. 


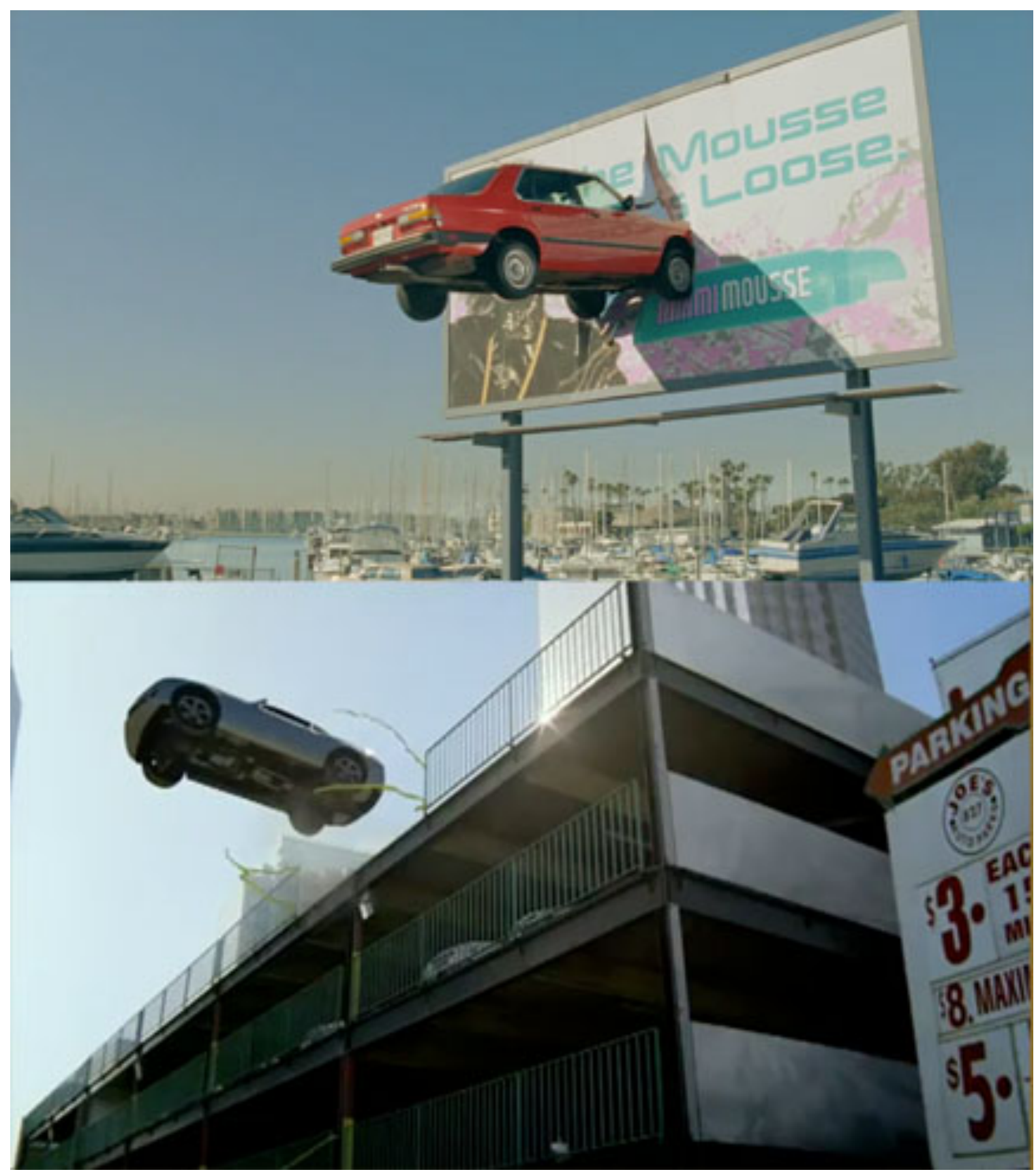

Figure 5. Comparison of Audi and Camaro jump shots. Copyright Volkswagen Group and Chevrolet. 


\section{ATTRACTIVE WOMEN IN LAVISH LIVING}

The next advertisement was selected because the results of the content analysis showed that the attractive woman in the ad (Megan Fox) is also a celebrity, which was relatively rare occurrence in the study. More often than not the attractive woman was designed to fit into a male fantasy that was at least somewhat believable/attainable. Celebrities are occasionally used to bolster merchandise associated with luxurious lifestyle, merit, comfort, and convenience. In the 2010 (non-recession year) Motorola Xoom ad featuring a disrobed Megan Fox, Fox is lounging seductively in a bathtub as she promulgates a Motorola phone with "Motoblur," a service that combines many social networking portals such as Facebook and Twitter. Although the sexual innuendo of the ad has little to do with the product, some studies suggest that the sex industry booms amid recessions. Men spent 8\% more money on sexual products and services between 2008 and 2009 ("With the recession going on in full swing," 2010). The commercial tells men that this a product an attractive woman appreciates. What's surprising isn't that Fox is having a bath with a product, but that she calls Motoblur "he." She also calls it "this little guy." The phonemakers want to get across that the product she is holding in her hand symbolizes or is an extension of the male viewer's body, perhaps even his genitals. The product (a phone) is the signified, implied by the signifier, the attractive woman (who the phonemakers want to associate their product with) and the tub (symbolic of a luxury item). 


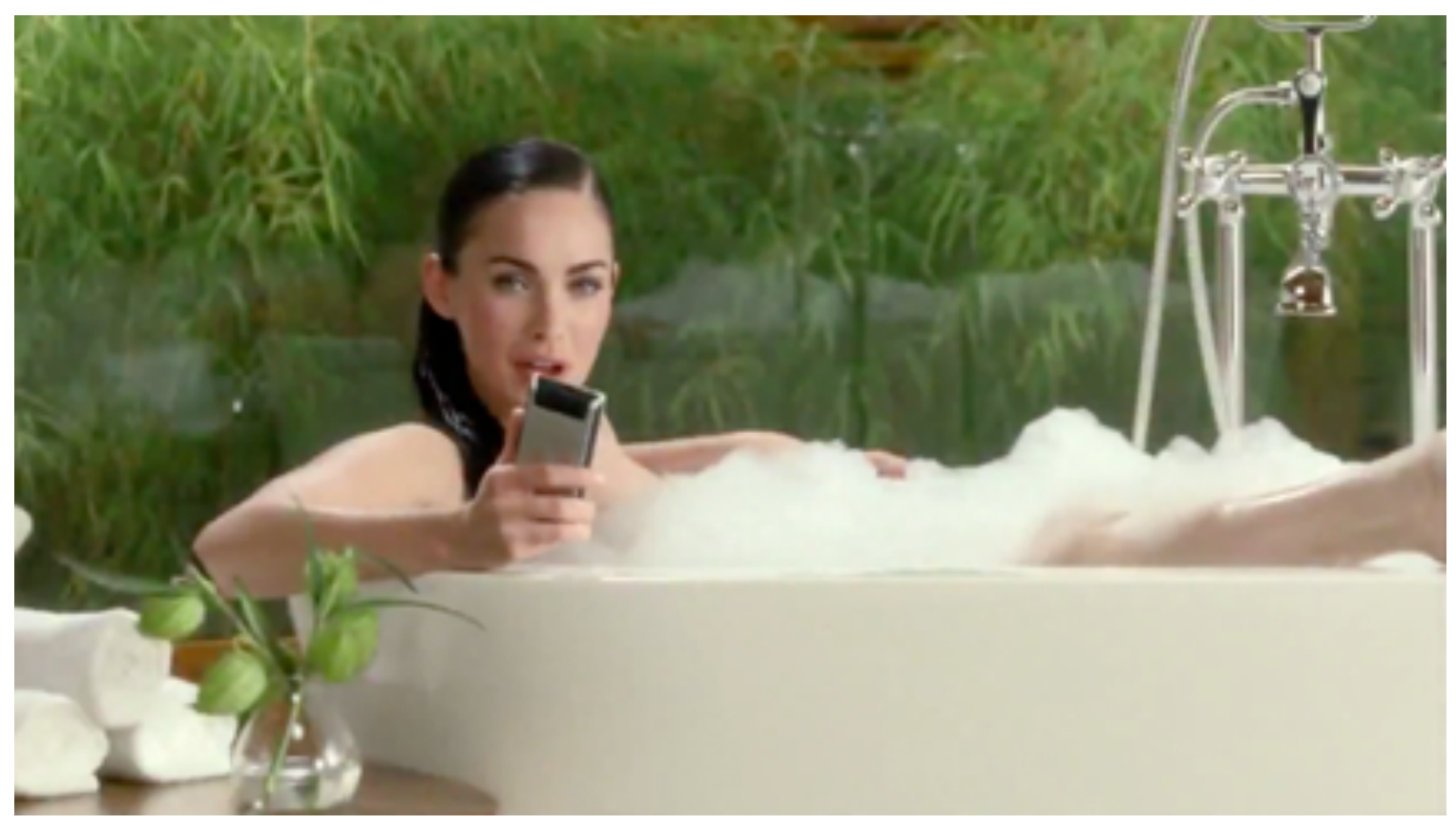

Figure 6. Megan Fox bathing with her Xoom. Copyright Motorola.

\section{DISCUSSION AND CONCLUSION}

The main question this study posed was what differences there would be in the usage of symbols and strategies in Super Bowl commercials during recession years versus nonrecession years. This study found through statistical analysis that although the results are not significant, the findings are indeed significant. The "strategies" aspect of the question was supported by the analysis. It found that neither tone, product references, symbols, celebrity inclusion, or product type were affected by the economic climate. This indicates that the ads agencies are not adjusting sales strategies based on the economy.

This study also found that the distribution of actors was surprisingly unevenly distributed throughout the commercials. Non-actor commercials were distributed more evenly over 
the six product type categories, while commercials with actors only appeared in 18 of the 40 commercials analyzed. Furthermore, actors were overwhelmingly concentrated in the automobile product type category $(\mathrm{N}=9,23 \%)$, which is equal to the other 6 categories combined. This would suggest that carmakers prefer to use celebrities in their commercials to tout their product (additionally, they may have more funds than the others). This could be interpreted with the proposition that celebrities represent desirable qualities and products they promote express an individual's self-esteem and social status. What the dominant use of the celebrity symbol in Super Bowl commercials says about symbols during recession years and non-recession years is that they are equally present no matter what the economic climate is.

This study found that the attractive woman symbol was distributed evenly across all product categories. This finding is consistent with the findings of Huang (2010), whose study showed that models are not relegated to any single type of product type. The only difference is that the models featured in his advertisements were advertising things such as diet, weight loss and exercise, cosmetics and fashion. It was beyond the scope of this study to analyze these types of ads as this study only pertained to Super Bowl commercials. Also, Huang's study analyzed print advertisements, while this study only analyzed commercials. Although commercials and print advertisements utilize different conventions, it seems significant that the findings are so similar.

The hypothesis that there would be more humorous commercials during a recession was not supported by the results of the data. The results for the years 2009-2012 were nearly 
indistinguishable, with $\mathrm{N}=7$ in $2009, \mathrm{~N}=8$ in $2010, \mathrm{~N}=8$ in 2011 , and $\mathrm{N}=9$ in 2012. This could be interpreted to mean that regardless of the economic climate, companies see humor as a successful way to market products to the Super Bowl audience. In the final analysis, there may be a better question to ask than what differences there are between symbols during recession vs. non-recession years. It may be more profitable to ask what similarities there are, for there is a surprising internal consistency to the meaning creation among the ads.

Humor is the touchstone of the average Super Bowl commercial. Celebrities are the symbolic lifeblood of commercials, especially ones advertising cars. Celebrities heavily populate the commercials, with a nearly 1:1 ratio of celebrity to non-celebrity ads. As speculated, the commercials reveal a lot about the deeper thoughts, desires, and inhibitions of the viewing public, as the commercials are like a mirror reflection of the American male's psyche. In the final estimation, one of the key findings of this study is that companies are not trying to stress affordability in their ads; they are trying to be inventive and amusing rather than worry about the bottom line.

The implications of these findings are manifold. Theoretically, they provide a system of ideas that can explain how and why commercials are made the way they are. If commercials are not conceptualized with the economy in mind, it stands to reason that they are made with other things such as creativity and innovation. This may be important to the process of the creation of meaning in commercials. This study has key research implications as well. It will help create a more learned perspective by enabling other 
interested researchers to build on the findings presented here. This study provides many categories for use in content analyses while leaving room for further investigation, and puts forth a template for semiotic analyses of advertisements that can be seen as a supplement to the work of Huang (2010).

\section{LIMITS AND FUTURE STUDIES}

This study used semiotic and content analysis to study the usage of symbols in commercials, and there is a depth to the subject that could only be briefly looks at in the scope of this project; it is like a peek into how a group of ads function. It is possible that interviews could be conducted with advertising agencies and product companies to better understand psychological effects, brand recall, and likability of particular ads.

Additionally, this study only looked at recent Super Bowl commercials (between 20092012), so there is not a dimension of long-range change, or an exposition of commercial, sports, and U.S. history. Finally, follow-up studies will be fruitful to diagram the transformation of symbols with the change of commercials in a developing American culture over a longer period of time. 


\section{REFERENCES}

Abberger, K, \& Nierhaus, W. (2008). How to define a recession? CESifo Forum, 9(4), 74-76.

Barthes, R. (1977). Image/Music/Text. NY: Hill and Wang.

Berger, A. (2000). Media and Communication Research Methods. CA: Sage Publications, Inc.

Braid, M. (2009). Laugh off all those fears of recession; During tough times can firms afford to spend money on injecting humour in the workplace? Mary Braid reports. The Sunday Times. January 11, 2009.

Danesi, M. (1994) Cool- The Signs and Meanings of Adolescence. University of Toronto Press.

Eisenstein, P. (1991, August 9). Before the film car chase, there's the real car chase. The Washington Times, p. 64.

Fleming, C. (2005). Transporter. Sight and Sound, 15, 81-82.

Freeman, M. (1999). Studies show Super Bowl ads scored with viewers. Media Week, February 8.

Friedman, V. ( 2009). Bags of fun puts humour into recession busting strategy: Giving her staff a sense of purpose with a sense of humour has paid off for designer Anya Hindmarch, writes Vanessa Friedman. Financial Times. 10.

Graham, R. \& Frankenberger, K. (2011). The earnings effects of marketing communication expenditures during recessions. Journal of Advertising, 40, 5-24.

Holmlund, C. (1986). Sexuality and Power in Male Doppelganger Cinema: The case of Clint Eastwood's “Tightrope.” Cinema Journal, 26 (1), 31-42.

Huang, Y. (2010). Constructing the West in Chinese magazine Advertising: A Content and Semiotic Analysis. (Doctoral Dissertation). Retrieved from ProQuest.

Hutchinson (Firm). gross domestic product. (2010). In The Hutchinson Unabridged Encyclopedia with Atlas and Weather guide. Retrieved from 
http://www.credoreference.com.www.libproxy.wvu.edu/entry/heliconhe/gross_do mestic product

Ketabi, S. \& Najafian, M. (2011). Advertising social semiotic representation: A critical approach. International Journal of Industrial Marketing, 1, 63-76.

Kotler, P. \& Caslione, J. (2009). How marketers can respond to recession and turbulence. Journal of Customer Behavior, 8, 187-191.

Kress, G \& Van Leeuwen, T. (2001). Multimodal Discourse: The Modes and Media of Contemporary Communication.NY: Arnold Publishers.

Kress, G. \& Van Leeuwen, T. (1996). Reading Images: The Grammar of Visual Design. NY: Routledge.

McAllister, M.P. (1999). Super Bowl advertising as commercial celebration. Communication Review, 3.403-28.

Mitu, B. (2011). Television's impact on today's people and culture. Economics, Management and Financial Markets, 6. 916-921.

Morgan, D. (2011). Most Americans say U.S. in recession despite data: poll. Reuters. Retrieved March 28, 2013 from http://www.reuters.com/article/2011/04/28/ususaeconomygallupidUSTRE73R3WW20110428?feedType $=$ RSS\&feedName $=$ domes ticNews

Neale, S. (1993). Masculinity as spectacle. Screen, 2-17.

Niazi, K., Ghani, U., Aziz, S. (2012). The emotionally charged advertisement and their influence on consumer's attitudes. International Journal of Business and Social Science. 3: 1, 307-320.

Okazaki, S. \& Mueller, B. (2011). The impact of the lost decade on advertising in Japan: A grounded theory approach. International Journal of Advertising, 30, 205-232.

Ostheimer, R. H. (1980). Magazine advertising during recessions. Journal of Advertising Research, 20 (6), 11-16.

Ponzio, A. (1993). Signs, Dialogue and Ideology. PA: John Benjamins Publishing Company.

Roderick, I. (2009). Bare life of the virtuous shadow warrior: The use of silhouette in military training advertisements. Journal of Media \& Cultural Studies, 23, 77-91.

Saussure, F. (1965). Course in General Linguistics. NY: McGraw-Hill. 
Smith, P. (1993). Clint Eastwood: A Cultural Production. Minneapolis, MN: University of Minnesota Press.

Srinivasan, R., Lilien, G. \& Sridhar, S. Should Firms spend more on research and development advertising during recessions? Journal of Marketing, 75, 49-65.

Stearns, P. (2008). Celebrity. In Oxford Encyclopedia of the Modern World. Oxford University Press.

Tellis, G. \& Tellis, K. (2009). Research on advertising in a recession. Journal of Advertising Research, 49, 304-327.

Veenstra, M. (2007). Motorcycles and motorcycle cultures. In Encyclopedia of Sex and Gender. (pp. 1039-1042). Detroit, Michigan: Macmillan Reference USA.

Vranica, S. (2012, January 3) Higher prices don't keep marketers away from ad time for Super Bowl. The Wall Street Journal.

Weber, R. (1990). Basic Content Analysis. London: Sage Publications, Inc. 


\section{APPENDIX}

\section{CODEBOOK}

The population for analysis consists of all Super Bowl commercials, and the sampling unit is 40 Super Bowl commercials from 2009, 2010, 2011, and 2012. This time period represents recent years when the GDP was at low and high points.

The unit of analysis is the individual commercial during the Super Bowl commercial breaks. Each unit must be coded for release information, for instance: 2012 , February $5^{\text {th }}$, Super Bowl number XLVI. There are three steps in coding an individual unit. First, the commercial must be identified; only the commercials from the Super Bowl received further coding. Next, place and time of the commercial premiere was coded for by identifying the year the commercial was aired during. Finally, commercial type was coded into one of a group of categories. A commercial is a single encapsulated entity and as such will be counted as a single unit. 
In order to provide a broad and most updated view of content in Super Bowl commercials, only commercials from 2009 through 2012 were analyzed. Forty commercials in total were analyzed, with 10 from each year. Each commercial was viewed all the way through before being coded. The first step was completing the content analysis. The semiotic analysis required more viewings and deeper study Categories included seven units: tone, product references, celebrity inclusion, product type, actor response to product, general symbols, specific symbols/signs. These units were chosen for their relevance to the semiotic analysis as well as by the patterns observed by the author while viewing Super Bowl commercials. They each addressed a different aspect of the overall symbolic language of a commercial, and helped determine what differences, if any, existed between ads during recession and non-recession years.

Tone: Tone is the overall ambience of the ad: humorous, serious, informative, cool. Humorous is synonymous with funny, which the Oxford English Dictionary defines as “affording fun, mirth-producing, comical, facetious." Serious is defined by the OED as "dealing with or regarding a matter on its grave side; not jesting, trifling, or playful; in earnest. Hence, of theatrical compositions or actors, not jocular or comic." Cool is defined as: an admired aesthetic of attitude, behavior, comportment, appearance and style, influenced by and a product of the Zeitgeist. The core of cool is a self-conscious aplomb which involves a set of behavioral qualities that are anchored in symbology (Danesi, 1994). 
Product references: The number of times a product is referenced in a commercial. In the Bud Light "Here Weego" commercial the dog bites different Bud Light bottles whenever a character yells "Here Weego!" (A play on the slogan "Here we go") and brings the bottles to them.

Celebrity inclusion: The 2012 Chrysler commercial would be a yes because it features Clint Eastwood. The 2012 Coca Cola commercial with polar bears would be an no. (A celebrity is a human being who famous outside of commercials. The OED defines celebrity as "the condition of being much extolled or talked about; famousness, notoriety").

Product Type: Most products sold in commercials can be classified as food, beverages, automobiles, entertainment, service industry, or technology.

Actor Response to Product: The characters in commercials have a set of reactions to products that elicit certain reactions in the viewer. For instance, a man might "win the girl" (victory) or satisfy his thirst (replenishment: which is also referred to as "stocking up").

General Symbols: There are general extrinsic symbols that occur in virtually all Super Bowl commercials. These include sports props, automobiles, attractive women, animals, and N/A. 
Although the categories were determined by the author to be exhaustive, it is possible there were certain cases where elements of more than one category were evident. In such a case, the coder examined the content and its context to determine its main focus, asking the question "what does this content show or express?" 